\title{
Study on the Path to Deepen Financial Cooperation Between Heilongjiang Province and Russia in New Situation*
}

\author{
Yanling Zhou \\ The School of Economics and Management \\ Heihe University \\ Heihe, China
}

\begin{abstract}
Financial cooperation is a necessary basis for the economic cooperation between China and Russia, but compared with the cooperation in other industries, the depth and scope of the financial cooperation between the two countries still need to be further improved. On this basis, this paper discusses the development of finance to Russia in Heilongjiang Province in detail from three aspects of external environment, existing problems and cooperation path.
\end{abstract}

Keywords-Heilongjiang; finance to Russia; international cooperation

\section{INTRODUCTION}

The Sino-Russian relationship is an important key point in "The Belt and Road Initiative". Russia is now looking for a stable and reliable financing source as support so that its future projects for a period of time can gain higher returns from capital market and infrastructure construction. China is constantly promoting the decentralization of foreign exchange reserves and RMB internationalization while looking for high return investment projects. Therefore, they provide a good foundation for the current financial cooperation between China and Russia. Seeing from the perspective of macro-economic development, whether the Russian financial system and economic system, which have experienced the global financial crisis and strong interference from external factors, can stay stable enough to support the sustainable development of Russian economy remains to be discussed. In addition, it seems that the risks of financial cooperation exist indeed if the financial cooperation scope is narrowed to financial cooperation between Heilongjiang Province and Russia. So it is necessary to further systematically study the financial cooperation between China and Russia and explore the path to deepen the financial cooperation between Heilongjiang Province and Russia under the new situation.

*Fund: Funding for Basic Scientific Research Operating Expense Research Project (Study on Strategies for Deepening Financial Cooperation between Heilongiiang Province and Russia in New Situation) in Heilongjiang Provincial Institutions of Higher Learning in 2019.

\section{EXTERNAL ENVIRONMENT FOR FINANCIAL CoOperation Between HeIlonguiang Province AND RUSSIA}

The primary task of China's current financial development is to grasp the opportunity of "The Belt and Road Initiative" to promote the financial cooperation and innovation in the countries along the "The Belt and Road" route. Looking back to the development process of Chinese financial reform and the development of Russian economy, the financial development in Russia is extremely unstable. Having gone through "Disintegration $\rightarrow$ Ruble depreciation $\rightarrow$ Asian financial crisis $\rightarrow$ Global economic downturn" and meanwhile dominated by Russia's "monetary policies", Russia's assets investment has been ignored in the international market by all countries. In recent years, Russia has learned lessons and started to gradually promote the "reform of fixed exchange rate system", and has been committed to the realization of "balance of payments surplus", gradually eliminating the losses arising from the international financial crisis. At the same time, under the background of policy reform, the Russia's financial development mechanism has gradually become mature, and the coordination of the Ministry of Finance and the Central Bank has shown a coordinated development trend, which is particularly prominent in the economic development after 2014. In the stable financial development environment, Russia's returns on investment and assets value have been gradually improved. Globally speaking, the ways of international financial cooperation are more and more diversified and many Asian countries have declared an open and positive attitude towards international cooperation. Although the financial cooperation between the two countries is still in the initial exploration stage compared with the Sino-Russian cultural and trade fields, "The Belt and Road" policy and the investment demands of Russia trigger a more and more obvious financial cooperation trend, meeting the interest needs of China and Russia in the foreseeable future.

At present, Russia's economic development is still "recovering", and the overall investment environment is relatively good. In the face of the increasing return on 
investment and increasing Sino-Russian cooperation projects, Russia also responds with a positive, welcome and open attitude, especially in the financial field, there is a new opportunity for Russia to fully accept China. In Russia's development plan, 2018-2024 is planned as a new period of "leap economic development" by Russia. How to rely on this round of economic development plan and explore the sustainable investment of external funds under the background of relatively short financial supply is the primary issue for the Russian government to consider. In response to this demand, China is the most realistic choice for Russia to meet its investment demand. With faster development in China's international finance field, the government has issued many policies to encourage the use of RMB for investment and loans, which is also China's development strategy for some time to come. Under the guidance of "The Belt and Road Initiative", the government has actively encouraged the "overseas industrial park construction" and "cross-border mergers and acquisitions" etc., achieving phased development market expansion and production capacity transfer, and the "Asian Infrastructure Investment Bank" led by "China" has been developing throughout the world, not only providing Russia stable financing for infrastructure construction, but also favorable to implementation of China's financial internationalization development strategy.

Since 2015, Russia has promoted financial development on the basis of "free floating exchange rate" adjustment so as to eliminate many risks brought by "inflation", and meanwhile avoid the rebound of inflation caused by tax policy reform. The benchmark interest rate has been adjusted from $7.25 \%$ to $7.5 \%$. Moreover, external factors, e.g. "interest rate increase by the Fed" and "economic sanctions", have also led the Central Bank of Russia to gradually increase interest rates, finally forming a complex corporate financing situation. Although Russia has not made clear of the interest rate increase strategy in the next stage, it can be roughly determined that, in a short period of time, there will be no interest rate cut. According to the speculation of the Russian Central Bank, inflation will start to fall in 2020. At present, the financing needs in Russia can be met through multiple channels, such as "financing to Russia", "bank loans" and "finance leasing", etc., while regional financial cooperation with Russia can form a good "win-win" situation.

\section{EXISTING PROBLEMS IN THE FINANCIAL COOPERATION WITH RUSSIA}

First of all, the current situation of financial cooperation with Russia reflects some practical problems, such as the blocked liquidation channel, and a perfect RMB-Ruble direct liquidation system has not yet established, especially the RMB -Ruble liquidation of the domestic high-value payment system has not yet been realized, although Heilongjiang Province has made many attempts. At present, China and Russia have signed a bilateral agreement on "local currency settlement". However, due to the small number of specific agent banks, the Central Bank of Russia has expressed relatively strict requirements on commercial banks, so that most of China's small and medium-sized commercial banks are unable to become agent banks of the Central Bank of Russia, directly hindering the cross-border circulation of Ruble and RMB. Furthermore, the Chinese and Russian banks signing the bilateral agreements on local currency settlement agency are mostly regional banks, most of which have few branches and gather in the provincial capitals of Far East Region or prefecture-level cities with better economic development, with no bank outlets in many small and medium-sized cities, which is difficult to meet the local currency settlement demand of Sino-Russian financial cooperation, restricting the normal operation of local currency settlement business in China and Russia.

Secondly, there are obvious bottlenecks in the cooperation between Chinese and Russian banks. On the one hand, they reflect in the insufficient Chinese bank branches set up in Russia and some problems in the scope and depth of business development. With the deepening of financial cooperation between China and Russia, it is urgent to further develop local currency financial business and promote the comprehensive integration of all aspects of financial business; on the other hand, they reflect in lack of an effective risk control mechanism in the cooperation between Chinese and Russian banks, insufficient trust and inadequate business information exchange between Chinese and Russian banks, lack of implementation of bank cooperation system and economic and trade development system, especially the lack of "risk control system". At present, Russia implements a strict guarantee mechanism for excess national debts, but Russian commercial banks generally do not provide effective guarantee for commercial banks. Now that the risks of financial development in Russia are difficult to predict, the Chinese banks, constrained by the risk control demand, are difficult to actively and comprehensively carry out financial services.

Finally, the problems about cash transfer have a great impact on the Sino-Russian in-depth cooperation and development. Although China Customs, the people's Bank of China, the Russian Customs and the Russian Central Bank have signed the agreement on cash transfer between the two places, the "high tariff of Russian Customs" causes an impact on the implementation of the agreement. If the cash transfer cost problem cannot be effectively solved, it has no way to realize RMB and Ruble supplying through SinoRussian financial cooperation. In addition, electronic payment still lacks a powerful tool. The electronic settlement products of China and Russia are single and the development of payment mode is only at the initial stage, unable to meet the diversified needs of financial cooperation.

\section{PATH FOR FINANCIAL COOPERATION BETWEEN HEILONGJIANG PROVINCE AND RUSSIA}

\section{A. Deepening Policy Support}

At present, the Border Development and Opening-up Plan for Heilongjiang Province and Northeast Regions of Inner Mongolia has been upgraded to a national development strategy, and Heilongjiang Region has been designated as the new position of national opening and development. 
Heilongjiang, as an important hub of Northeast Asian Development and financial development to Russia, will, under the guidance of the State Council, build the ChinaMongolia-Russia Economic Corridor into a vital link connecting the north and the south and crossing from the east to the west, and gradually form an open economic pattern, which plays an important role in promoting the economic development in Heilongjiang Province. In view of the problems existing in the current financial cooperation with Russia, it is suggested to deepen policy support, promote the implementation of policies, and optimize the financial cooperation relationship with Russia through policies. Firstly, solve the agency problem of Russian banks, advocate the establishment of "dual currency" accounts, so as to solve the settlement problem and flat plate clearing problems; secondly, impel commercial banks to actively change the local currency settlement mode, create diversified financial products according to the mode of financial cooperation with Russia, and further expand the coverage of local currency settlement; thirdly, actively promote bilateral local currency settlement business, further clarify the business types to ensure that cross-border bank cards can both complete the payment business and meet the demand for cash withdrawal; fourthly, under the background of the gradual stability of Russian finance, guide commercial banks to actively open international business in border trade areas, so as to promote the realization of RMB internationalization in Russian border port areas.

\section{B. Strengthening Financial Capability}

It is necessary center around Harbin City, Heilongjiang Province to build a financial settlement center for Russian business relying on some specific methods such as "collection", "letter of guarantee", "letter of credit" and "overseas payment", etc., so as to continue supporting the cooperation between overseas banks and Heilongjiang financial institutions. And meanwhile, it is a must to improve the trade financing system and optimize it according to the current financial policies implemented by Shanghai Free Trade Zone and in combination with the actual situation in Heilongjiang, so as to improve the smoothness of supply and demand channels for financing to Russia and provide convenience for financial cooperation with Russia. In addition, it is also required to actively cultivate the SinoRussian bond market, continuously develop venture and industrial investment funds, as well as improve the futures trading market and equity trading market on the basis of integrating various types of regional resources.

\section{Innovating Service Mode}

First, it is necessary to further enrich the means of payment and build a cross-border payment center, through introducing domestically mature third-party payment platform and supporting e-commerce in Heilongjiang Province to interface with Russian banks or Russian thirdparty payment institutions under certain constraint conditions, and meanwhile encouraging the cooperation between thirdparty payment platforms and commercial banks to give full play to the advantages of Heilongiiang Province in economic cooperation with Russia by means of B2B, fast payment.
Second, it is required to pay close attention to the construction process of Harbin Comprehensive Bonded Zone, actively advocate the entry of financial institutions, further expand the business scale of financial institutions through institutional introduction and policy pilot, and provide good support for foreign banks to set up branches, so as to gradually build a perfect framework of financial services to Russia. Third, it is needed to develop a diversified financial service system, with traders and investors as service objects, to provide dynamic and diversified trade information and provide reliable and detailed basis for better cooperation between the two sides.

\section{CONCLUSION}

From the above, compared with developed countries, Chinese financial development level is still relatively backward, which requires China to actively promote the financial system globalization, improve the resource allocation ability of Chinese-funded financial institutions, as well as upgrade China's influence in global capital operation. In fact, in the current situation, China and Russia need to do more around the world, which not only meets Russia's economic development needs, but also conforms to China's interest appeals. Heilongjiang Province is an important area for the construction of Northeast Asian economic circle and the development of economy to Russia. In view of the current problems, it still needs to be optimized and improved from many aspects, so as to truly promote the sustainable development of Sino-Russian economy, trade and finance.

\section{REFERENCES}

[1] Zhang Wutao, Su Lu. Study on Issues and Strategies on Financial Cooperation between Heilongjiang Province and Russia under the Background of "Longjiang Silk Road Belt" $[\mathrm{J}]$. China Economist, 2019(9):165, 223 (in Chinese).

[2] Fang Hong. Study on Strategies of Heilongjiang Province for Financial Cooperation with Russia[J]. China Economist, 2017(3):173174(in Chinese).

[3] Wang Lizhi. Zheng An'an. Analysis of Financial Supports for Agricultural Products Trade between Heilongjiang Province and Russia[J]. Foreign Economic Relations \& Trade, 2017(1):53-55(in Chinese)

[4] Liu Zhenliang, Study on the Path of Financial Cooperation between Heilongjiang Province and Russia under the background of "The Belt and Road Initiative"[J]. Economic Research Guide, 2018(8):139140(in Chinese). 